\title{
Erratum to: A case of amniotic membrane transplantation in non-healing Nocardia asteroides keratitis
}

Firoozeh Rahimi • Masoud Aghsaei Fard •

Reza Soltani Mogaddam

Published online: 7 April 2010

(C) Springer Science+Business Media, LLC 2010

Erratum to: j ocul biol dis inform

DOI 10.1007/s12177-009-9019-5

In the original publication, the surname of the second author was incorrectly captured. The author's abbreviated name should read M. A. Fard.

The online version of the original article can be found at http://dx.doi. org/10.1007/s12177-009-9019-5.

F. Rahimi $\cdot$ M. A. Fard $(\bowtie) \cdot$ R. S. Mogaddam

Farabi Eye Research Center, Department of ophthalmology,

Tehran University of Medical Sciences,

Quazvin Sq.,

Tehran, Iran 1336616351

e-mail: masood219@yahoo.co.uk 